\title{
A Portable and Mobile Rainfall Simulator
}

\author{
Robert J. Lascano ${ }^{*}{ }^{\mathbb{1}}$, John E. Stout ${ }^{1}$, Timothy S. Goebel ${ }^{2}$, Dennis C. Gitz III ${ }^{1}$ \\ ${ }^{1}$ Wind Erosion and Water Conservation Research Unit, USDA-ARS, Lubbock, TX, USA \\ ${ }^{2}$ Department of Plant and Soil Science, Texas Tech University, Lubbock, TX, USA \\ Email: *Robert.Lascano@ars.usda.gov
}

How to cite this paper: Lascano, R.J., Stout, J.E., Goebel, T.S. and Gitz III, D.C. (2019) A Portable and Mobile Rainfall Simulator. Open Journal of Soil Science, 9, 207-218.

https://doi.org/10.4236/ojss.2019.910012

Received: September 7, 2019

Accepted: October 7, 2019

Published: October 10, 2019

Copyright $\odot 2019$ by author(s) and Scientific Research Publishing Inc. This work is licensed under the Creative Commons Attribution International License (CC BY 4.0). http://creativecommons.org/licenses/by/4.0/

\section{Open Access}

\begin{abstract}
An existing Purdue-type rainfall simulator (RFS) was designed to be transported using a commercial flatbed trailer that was modified by cutting out a section of the wooden bed allowing the RFS to be positioned directly above the target area to measure soil erosion and water runoff. To allow water to pass through the trailer undisturbed, the axle of the trailer was removed and replaced with axle-free wheel hubs and springs. Additionally, a remote control mover rated for $2000 \mathrm{~kg}$ was incorporated in our design. The final result was a portable and mobile RFS that can be moved to fields using a trailer hitch and can be operated by two individuals. The cost of the hardware, not including the RFS, is $\$ 5300$ (USD) and detailed design plans are available.
\end{abstract}

\section{Keywords}

Mobile, Transport, Trailer, Plot and Field Studies, Infiltration, Runoff, Soil Erosion

\section{Introduction}

Rainfall simulators (RFS) are tools that are used to apply water to plots as a means to simulate and observe the effects of natural rain events, e.g., [1] [2]. Natural rainstorms have intensities resulting from variable drop-size distribution and kinetic energy [3] [4]. For a given rain event, a large fraction of the total rainfall can be delivered during a short time and these high intensity peaks can occur anytime during the rain event. Furthermore, during high intensity periods, raindrops can become larger with greater fall velocities resulting in higher kinetic energy for the storm. These two rainfall properties-variable intensity and drop-size distribution characteristics-need to be duplicated by a RFS to accurately quantify the effects of rain in soil erosion and other hydrological processes, such as infiltration, runoff, sediment and nutrient transport, among others. 
There is an extensive body of literature related to RFS and their design and use in soil erosion studies and comprehensive reviews are given by [5] [6] [7] [8] and more recently by [9].

In general, RFS can be categorized according to their transportability, indoor and outdoor, and by how the simulator generates rain, non-pressurized, where raindrops fall due to gravity, and pressurized, where raindrops are delivered from a single or multiple nozzles [2] [10] [11] [12]. In the non-pressurized group, for a rain of a desired size, the drop is formed at the tips of hanging threads, glass capillary and stainless tubes, or hypodermic needles. In this type of RFS, the drops fall when their weight overcomes the surface tension and fall due to gravity. In the pressurized-nozzle type, a RFS can produce raindrops through single or multiple nozzles using a rotating disc or boom, and an oscillating bar or solenoid-controlled simulator that can be used to start or stop the spray, e.g., [13] [14] [15] [16].

The pressurized-nozzle type RFS is often used for field applications and has been modified and improved over the last two decades. For example, a RFS producing variable intensities and kinetic energies similar to natural rain was described by [17]. A solenoid-operated variable intensity RFS was described by [18]. A RFS where the intensity of a simulated rain event could be adjusted while raining with a computer that controlled the spray nozzles exposure time was described by [19]. Similarly, a computer-controlled RFS that varied both the intensity and the kinetic energy of the raindrops, and also measured runoff and recorded rain application and runoff data was developed by [2]. These modifications improved the use of RFS for field investigations and the introduction of microprocessors and computers have facilitated spray nozzle control and data collection [11] [20].

Most RFS are custom built and their design can vary from simple, e.g., [8] [21] [23] to complex, e.g., [2] [10] [24] depending on their specific application. With regard to components, field RFS typically have the following parts: 1) water applicator, including solenoid-valves and nozzles; 2) suspension frame and tarp; 3 ) water supply and pump; 4) runoff collection; 5) power supply; 6) computer control; and 7) boom [2] [11] [15] [22] [25]. However, an additional component that is necessary for field applications but is seldom mentioned is the trailer or mechanism used to transport the RFS between fields and between sampling plots. Regardless of the simulator used, a RFS for field studies should meet the following design criteria to accurately simulate rain events [2] [10]: 1) raindropsize distribution and terminal velocities similar to those of natural rain events; 2) uniform intensity and random raindrop-size distribution across the measurement or target area; 3) near vertical impact of raindrops on the target area; 4) reproducible rain patterns for both duration and intensities; 5) low cost and portability; and 6) user-friendly control systems. Of these criteria much work has been on improving the "engineering" components of the RFS by selecting appropriate nozzles that in combination with oscillating mechanisms duplicate 
the variable intensity and drop-size distribution of rain events, e.g., [10] [13] [14] [18] [20] [26]; and others. However, modifications to improve the portability and mobility of RFS for field applications have been marginal. Therefore, the main purpose of our work was to develop and build a mechanism to transport and deploy, using a commercial trailer, a RFS for field applications that minimized labor and improved portability and mobility. For this purpose, we used a Purdue-type RFS, which has been described by [27] [28] [29] [30]. A detailed description of this type of RFS is given by [31]. Herein, we describe parts used and provide detailed mechanical drawings that describe the construction of the trailer used with our RFS.

\section{Materials and Methods}

One goal of our design was to use the RFS while it was directly mounted on the trailer without having to detach and manually move it into position, as normally done. This design reduces the time required to move the RFS and expedites the measurement of infiltration and runoff, and other measurements. For this purpose, we selected and used a commercial flatbed general single axle utility trailer 14 feet $(4.3 \mathrm{~m})$ in length $\times 77$ inches $(2.0 \mathrm{~m})$ in width that was acquired from a local dealership (Figure 1). Specifically, the trailer was a Model PSA, Diamond C Series Trailer Mfg., Mt. Pleasant, TX, with a gross vehicle weight rating of 2990 pounds $(1356 \mathrm{~kg})$, with 2 -inch $(5.1-\mathrm{cm})$ treated lumber for the bed, ST205/75SD15
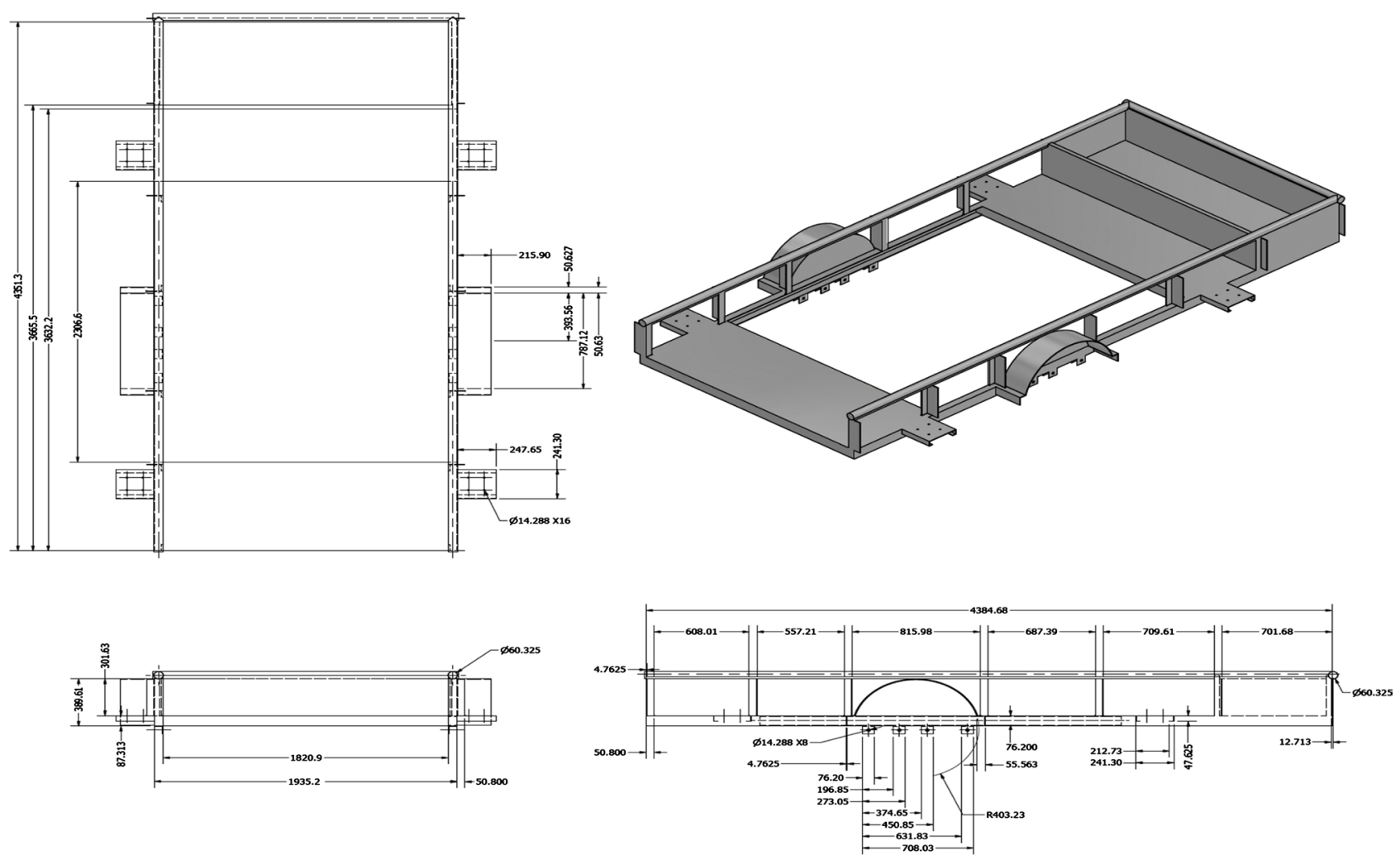

Figure 1. Schematic diagram of commercial flatbed trailer used to transport the rainfall simulator. The scale of the drawing is 1 $\mathrm{cm}=0.5 \mathrm{~m}$. 
tires (ST is for Special Trailer, 205 is the section width of the tire in $\mathrm{mm}, 75$ is the aspect ratio or section height, $\mathrm{D}$ is the diagonal or bias ply construction, and 15 is the wheel diameter in inches, $381 \mathrm{~mm}$ ), and 3500 pound (1588 kg) E-Z Lube, Idler axles. This axle as the name implies, is relatively easy to lubricate. A $2.3 \mathrm{~m}$ long $\times 1.8 \mathrm{~m}$ wide section of the wooden bed of the trailer was cut to accommodate the base of the RFS, as shown in Figure 1 and Figure 2. A list of the trailer parts used to transport the RFS is given in Table 1 and the corresponding number of each part is shown in Figure 3.

To lower the RFS while mounted on the trailer and position it directly above the measurement plot requires the removal of the single axle (Part No. 8, Figure 3 ) so that it would not interfere with the wetting of the plot (see Part No. 8, Table 1 and Figure 3). Information on modifications to the springs is shown in Figure 4 (see Part No. 10, Table 1). It is important to note that the removable axle has to be inserted and be in place when the trailer is being towed by a vehicle at highway speeds not to exceed 55 miles $/ \mathrm{h}(89 \mathrm{~km} / \mathrm{h})$. Towards the front of the trailer, a compartment to store tools and other equipment was added.

The ability to remove the axle while maintaining the structure of the wheel hub (Part No. 18, Figure 3) required modification of the two springs (Part No. 10, Figure 3), one per wheel. This included the shaft (part No. 9, Figure 3) and a variety of nuts (Parts 13, 16 and 19, Figure 3), bolts (Part No. 12 and 19, Figure 3),
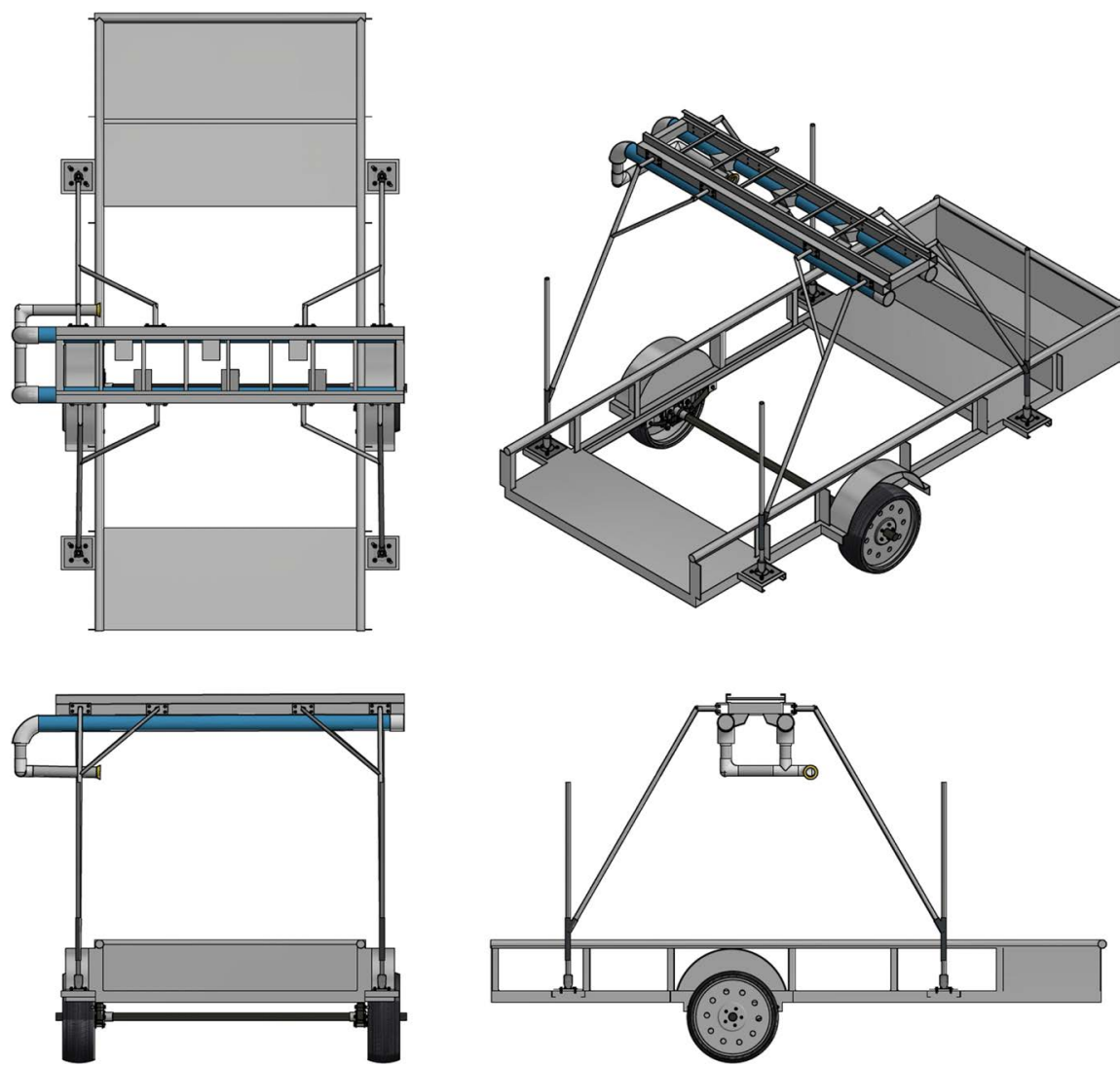

Figure 2. Different views of the rainfall simulator positioned over the wooden base of the flatbed trailer. The scale of the drawing is $1 \mathrm{~cm}=0.5 \mathrm{~m}$. 
Table 1. List of parts used in the rainfall simulator. Given are the quantities of each item, their description and the part number that corresponds to the number shown in Figure 3.

\begin{tabular}{|c|c|c|c|}
\hline Part Number & Quantity & Item & Description \\
\hline 1 & 1 & Commercial Trailer & $\begin{array}{l}14 \text { feet } \times 77 \text { inches [Length } \times \text { Width] } \\
\qquad(4.3 \times 2 \mathrm{~m})\end{array}$ \\
\hline 2 & 33 & Nut & $9 / 16-18^{*} \mathrm{UNF}^{*}[(14.3 \mathrm{~mm})-7 / \mathrm{cm}]$ \\
\hline 3 & 4 & Metal Plate & $4 " \times 4 "(10.2 \times 10.2 \mathrm{~cm})$ \\
\hline 4 & 12 & Washer & 9/16" Hole Flat (14.3 mm) \\
\hline 5 & 16 & Washer & 1/4" Hole Flat (6.4 mm) \\
\hline 6 & 12 & Bolt & $1 / 4-20 \mathrm{UNC}^{\star}[(14.3 \mathrm{~mm})-8 / \mathrm{cm}]$ \\
\hline 7 & 16 & Bolt & 9/16-18 UNF $[(14.3 \mathrm{~mm})-7 / \mathrm{cm}]$ \\
\hline 8 & 1 & Axle & 8 feet $(2.4 \mathrm{~m})$ Length \\
\hline 9 & 2 & Shaft & \\
\hline 10 & 2 & Spring & \\
\hline 11 & 2 & Star & \\
\hline 12 & 16 & Bolt & 9/16-18 UNF [(14.3 mm) - 7/cm] \\
\hline 13 & 17 & Nut & 9/16-18 UNF [(14.3 mm $)-7 / \mathrm{cm}]$ \\
\hline 14 & 8 & Strap No. 1 & \\
\hline 15 & 8 & Strap No. 2 & \\
\hline 16 & 8 & Nut & 9/16-18 UNF $[(14.3 \mathrm{~mm})-7 / \mathrm{cm}]$ \\
\hline 17 & 4 & Pipe Connect & \\
\hline 18 & 2 & Wheel & ST205/75D15 \\
\hline 19 & 10 & Bolt & 9/16-18 UNF $[(14.3 \mathrm{~mm})-7 / \mathrm{cm}]$ \\
\hline 20 & 10 & Nut & 9/16-18 UNF $[(14.3 \mathrm{~mm})-7 / \mathrm{cm}]$ \\
\hline
\end{tabular}

${ }^{*} \mathrm{UNF}=$ United National Fine Thread; ${ }^{+} \mathrm{UNC}=$ United National Coarse Thread; ${ }^{*}$ Thread Standards and Definitions: [9/16"-18] is 18 threads per inch, equivalent to [14.3 $\mathrm{mm}-7 / \mathrm{cm}]$;

https://www.engineeringtoolbox.com/unified-screw-threads-unc-unf-d_1809.html.

Strap No. 1 (Part No. 14, Figure 3), Strap No. 2 (Part No. 15, Figure 3), shaft (Part No. 9, Figure 3) and star (Part No. 11, Figure 3). The inclusion of the star (Part No. 11, Figure 3) allows both the rapid removal of the axle to lower the RFS and to reinsert the axle when necessary for transport. A detailed diagram of the spring and axle parts is shown in Figure 4 and a depiction of the axle in the wheel hub from different angles is shown in Figure 5.

The framework used to attach the RFS to the trailer is given in Figure 6 and a list with part numbers for the items shown in Figure 6 is given in Table 2. To do so, four brackets were first welded to the sides of the trailer and four plates (Part No. 3, Figure 3) were used to connect (Part No. 1, Table 2) the RFS using four beams (Part No. 2, Table 2). This design provided a rigid framework to support the RFS on the trailer.

Another feature of our design was to incorporate the use of a remote controlled 


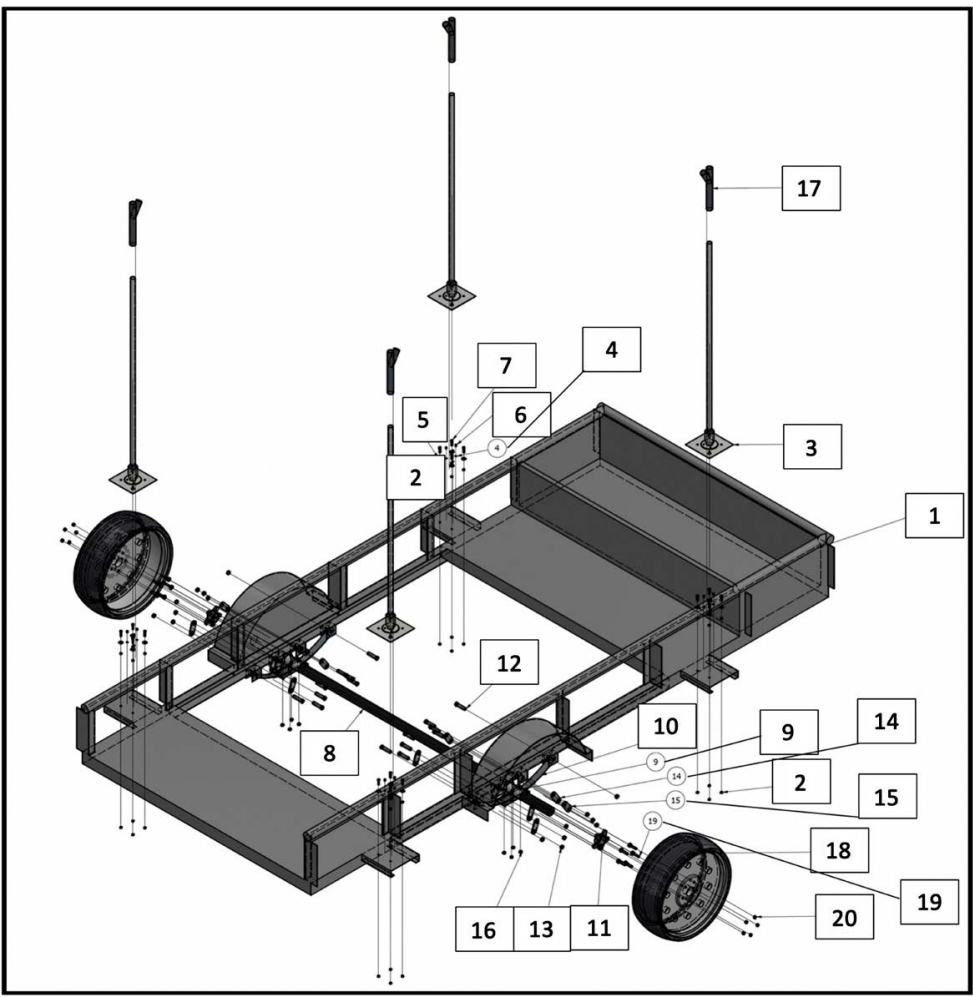

Figure 3. Schematic diagram of the flatbed trailer used to transport the RFS. The numbers shown correspond to the item number shown in Table 1 . The scale of the drawing is $1 \mathrm{~cm}=0.5 \mathrm{~m}$.
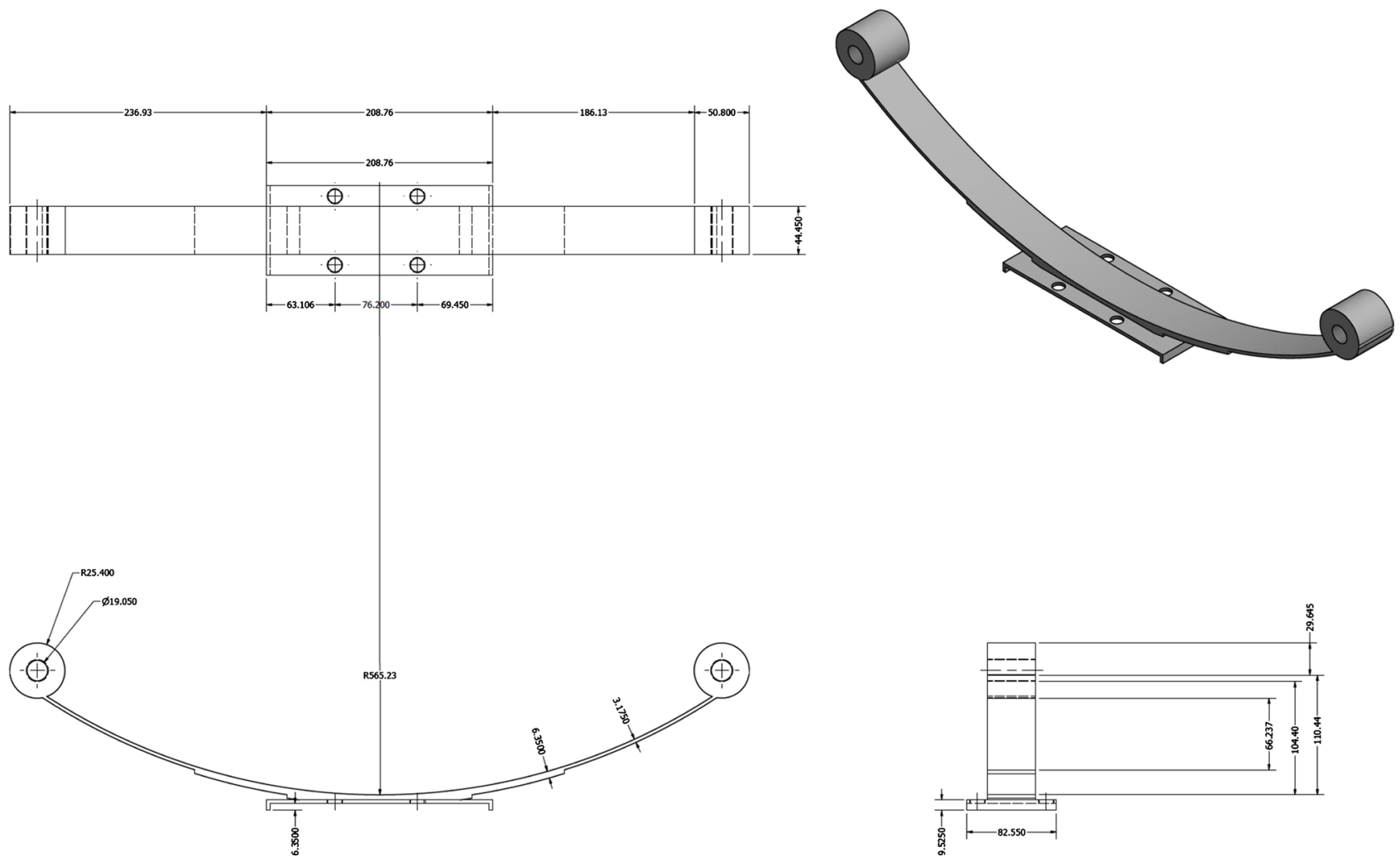

Figure 4. Schematic diagram of the spring mounted on the wheel hub to support the tire mounted to the lower frame of the flatbed trailer. The scale of the drawing is $1 \mathrm{~cm}=0.5 \mathrm{~m}$. 


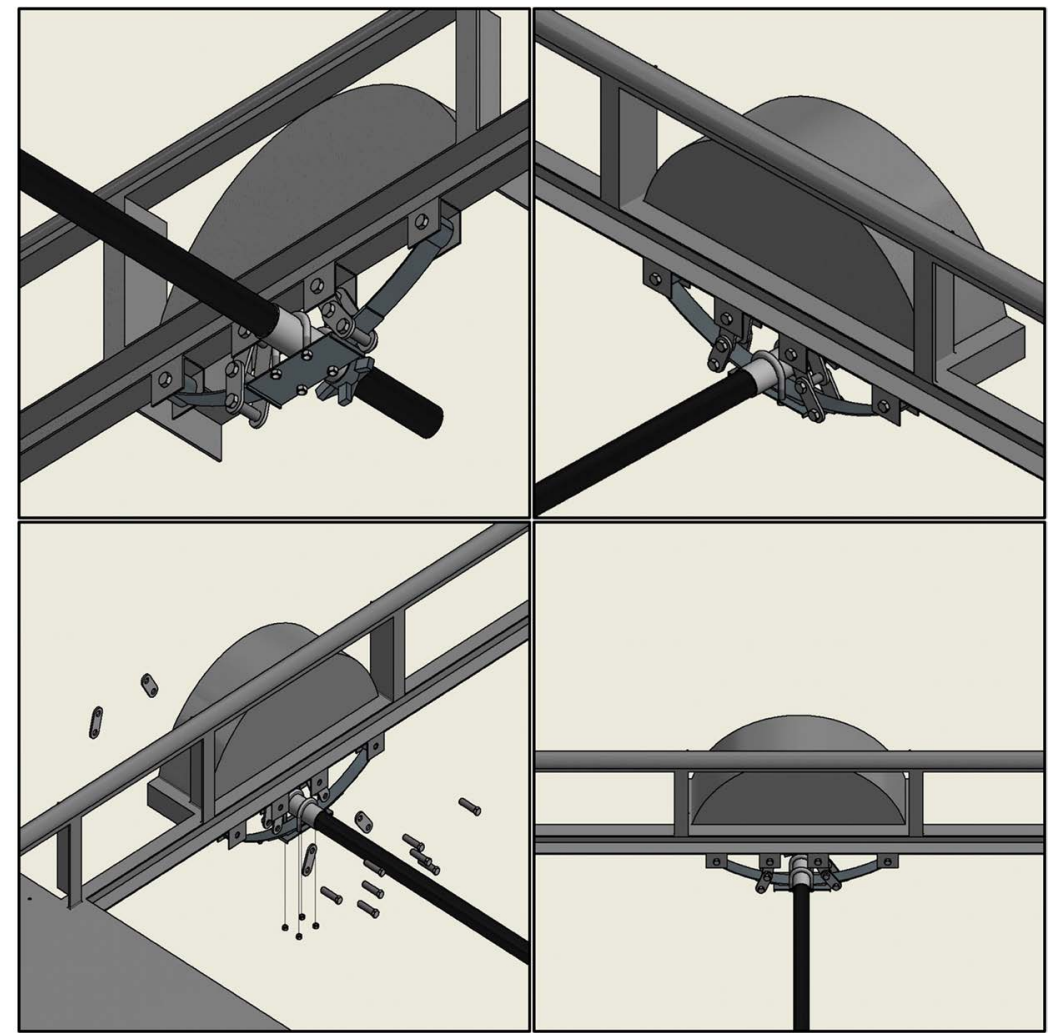

Figure 5. Different views of the axle and wheel hub assembly on the flatbed trailer. The scale of the drawing is $1 \mathrm{~cm}=0.5 \mathrm{~m}$.

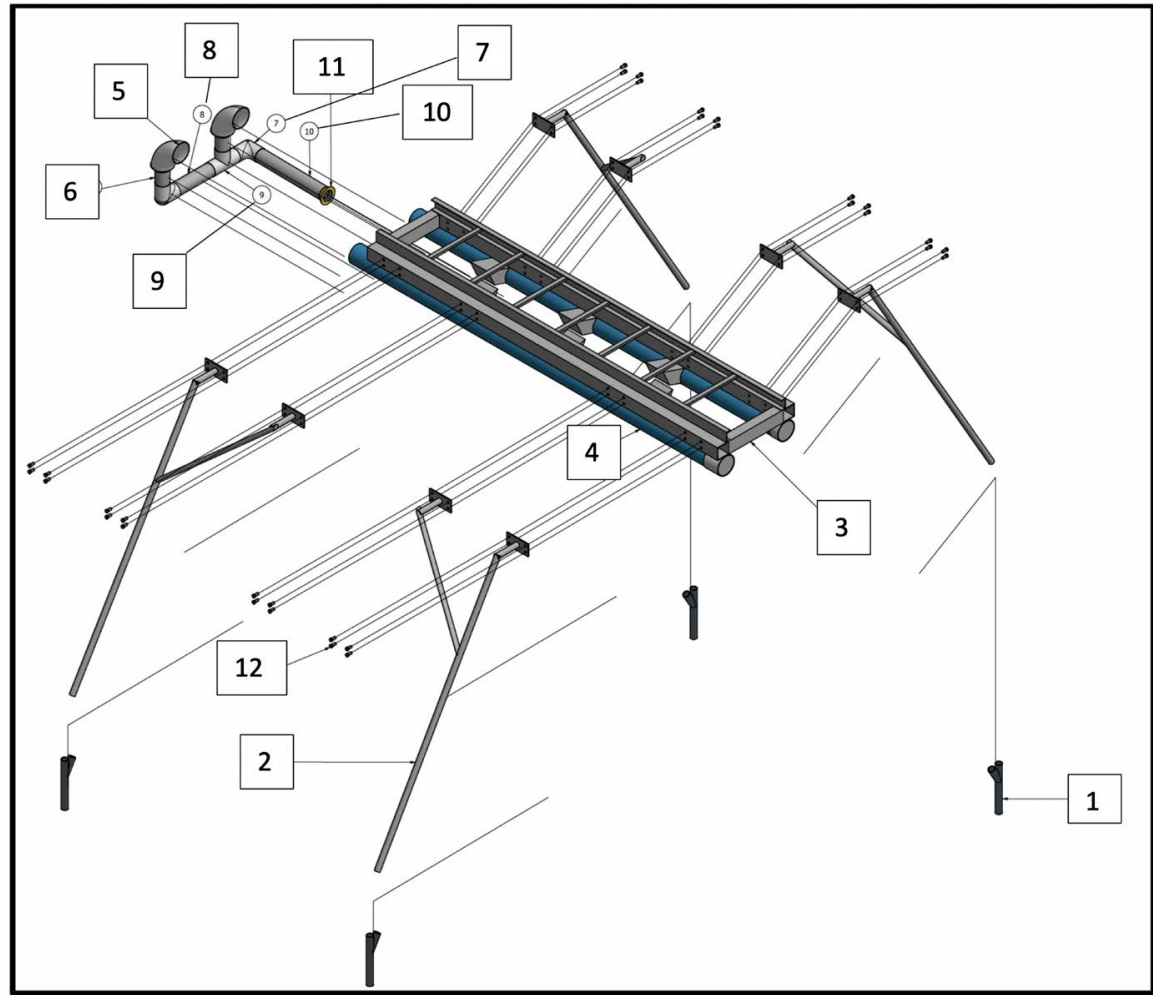

Figure 6. Framework used to attach the RFS to the flatbed trailer. The numbers shown correspond to the item number shown in Table 2. The scale of the drawing is $1 \mathrm{~cm}=0.5 \mathrm{~m}$. 
Table 2. List of parts used in the pipe assembly of the RFS. Given are the quantities of each item, their description and the part number corresponds to the number shown in Figure 6.

\begin{tabular}{cccl}
\hline Part Number & Quantity & Item & \multicolumn{1}{c}{ Description } \\
\hline 1 & 1 & Trailer/Pipe Connect & \\
2 & 4 & Beam & \\
3 & 1 & Ladder & \\
4 & 2 & Pipe & PVC $C^{\star}, 4.5$-inch $(11.4-\mathrm{cm})$ Diameter \\
5 & 2 & Pipe Elbow & PVC, 4.5-inch $(11.4-\mathrm{cm})$ Diameter \\
6 & 2 & Pipe & 4.5-inch $(11.4-\mathrm{cm})$ Diameter, 5-inch $(12.5-\mathrm{cm})$ \\
7 & 2 & Pipe Elbow & PVC, 3.5-inch $(8.9-\mathrm{cm})$ Diameter \\
8 & 1 & Pipe & 4.5 -inch $(11.4-\mathrm{cm}), 10-$ inch $(25.4-\mathrm{cm})$ Length \\
9 & 1 & Tee & 4.0 -inch $(10.2-\mathrm{cm})$ PVC Tee \\
10 & 1 & Pipe & 4.5 -inch $(11.4-\mathrm{cm})$ Diameter, 12-inch $(30.5-\mathrm{cm})$ \\
11 & 1 & Length \\
12 & 32 & Bolt & $1 / 2-13$ UNC $[(12.7$ mm $)-5 / \mathrm{cm}]$ \\
\hline
\end{tabular}

${ }^{*} \mathrm{PVC}=$ polyvinyl chloride.

robot to maneuver the trailer into position above the sampling plot. For this purpose we used a Model CT1500 "trailer valet" manufactured by Kronings of Ebsjerg, Denmark. This particular model has the following specifications: nominal power $=0.118 \mathrm{~kW}$; rated voltage $=14.8$, battery capacity $=6.6 \mathrm{Ah}$; maximum vertical load $=2940 \mathrm{~N}$, maximum drawbar pull $=14,700 \mathrm{~N}$, and a mass $=$ $20 \mathrm{~kg}$. The use of this device allows a single operator to transport the trailer with the RFS to a measurement site and to use the trailer valet to move the trailer with the RFS over the field plot and thereafter to other locations.

\section{Results and Discussion}

The time needed to acquire the trailer and purchase the required parts was approximately 30 days with one technician doing assembly, modifications, welding and construction. We estimated that the technician spent 32-man hours on construction and assembly and 32-man hours on welding. By far the task that was the most time-consuming was the spring assembly (40-man hours) and the design to remove the axle from the wheel hub (40-man hours). This was a "trial and error" process that ultimately resulted in a very robust design that was tested with excellent results.

The normal operation of a Purdue-type RFS requires a minimum of two to four individuals depending on the measurements planned. For example, for routine measurements of simulating three rainfall patterns on bare and cultivated soil requires at least three individuals to move the RFS between plots, connect hoses run pumps and collect data. With the RFS on the trailer, we speculate that 
one person would be able to do all the necessary tasks to accomplish all measurements and data collection. However, for our purpose and that for routine use of our RFS we recommend two individuals to carry out field measurements. This recommendation is partly based on safety, particularly when measurements are obtained in remote areas.

Based on our experiences, and for routine measurements with our RFS mounted on a trailer required about one hour to setup the initial deployment of the equipment. Thereafter, the RFS can be moved to a different site (plot) in the same field in less than 30 minutes using the trailer valet to tow the RFS. Naturally, these times will vary depending on experimental design, number of replicates needed and other factors.

The cost of hardware used to build the portable RFS was, $\$ 800$ (USD) for parts, $\$ 1500$ (USD) for a used trailer, and $\$ 3000$ (USD) for the robot, for a total of $\$ 5300$ (USD). This value is subject to change and the cost of the trailer-valet represented $57 \%$ of the total cost. Further, the value of labor is not included as this cost is subject to vary significantly and also the cost of the RFS is not included. In our design, we used a Purdue-type RFS; however, other RFS could be used provided that the width of the RFS does not exceed the width of the flatbed trailer, i.e., $2.0 \mathrm{~m}$.

\section{Summary and Conclusion}

We describe a Purdue-type rainfall simulator that was adapted to be mounted on a flatbed trailer above an opening on the bed of the trailer, allowing the rainfall simulator to be lowered and placed directly and in contact with the target area for measurements of soil erosion and water runoff. The trailer was modified such that the axle could be removed when the RFS was in use and could be re-inserted when the RFS was being transported between fields. The design of the axle required modifications to the springs mounted on the wheel hubs of the trailer. We estimated that the total cost of hardware was $\$ 5300$ (USD) and that routine measurements of soil erosion and water runoff could be done with two individuals. Please contact us for detailed information on the design of our portable and mobile rainfall simulator.

\section{Declaration}

The US Department of Agriculture (USDA) prohibits discrimination in all its programs and activities on the basis of race, color, national origin, age, disability, and where applicable, sex, marital status, familial status, parental status, religion, sexual orientation, genetic information, political beliefs, reprisal, or because all or part of an individual's income is derived from any public assistance program. (Not all prohibited bases apply to all programs.) Persons with disabilities who require alternative means for communication of program information (Braille, large print, audiotape, etc.) should contact USDA's TARGET Center at (202) 720 - 2600 (voice and TDD). To file a complaint of discrimination, write to USDA, 
Director, Office of Civil Rights, 1400 Independence Avenue, S.W., Washington, DC 20250-9410, or call (800) 795-3272 (voice) or (202) 720-6382 (TDD). USDA is an equal opportunity provider and employer. Mention of trade names or commercial products in this publication is solely for the purpose of providing specific information and does not imply recommendation or endorsement by the USDA.

\section{Acknowledgements}

We thank Mr. Dean Holder who did all the construction and design of the trailer. We are also grateful to Mr. Sergio Hernandez-Acosta, undergraduate student in Mechanical Engineering at Texas Tech University, who was responsible for all the CAD drawings. This research was supported in part by the Ogallala Aquifer Program, a consortium between USDA-Agricultural Research Service, Kansas State University, Texas A \& M AgriLife Research, Texas A \& M AgriLife Extension Service, Texas Tech University, and West Texas A\&M University.

\section{Conflicts of Interest}

The authors declare no conflicts of interest regarding the publication of this paper.

\section{References}

[1] Moore, I.D., Hirschi, M.C. and Barfield, B.J. (1983) Kentucky Rainfall Simulator. Transactions of the American Society of Agricultural Engineers, 26, 1085-1089. https://doi.org/10.13031/2013.34081

[2] Lascano, R.J., Vorheis, J.T., Baumhardt, R.L. and Salisbury, D.R. (1997) ComputerControlled Variable Intensity Rain Simulator. Soil Science Society America Journal, 61, 1182-1189. https://doi.org/10.2136/sssaj1997.03615995006100040025x

[3] Laws, J.O. and Parsons, D.A. (1943) The Relation of Raindrop-Size to Intensity. Transactions American Geophysical Union, 24, 452-460. https://doi.org/10.1029/TR024i002p00452

[4] Huff, F.A. (1967) Time Distribution of Rainfall in Heavy Storms. Water Resources Research, 3, 1007-1019. https://doi.org/10.1029/WR003i004p01007

[5] Mutchler, C.K. and Hermsmeier, L.F. (1965) A Review of Rainfall Simulators. Transactions of the American Society of Agricultural Engineers, 8, 67-68. https://doi.org/10.13031/2013.40428

[6] Rennard, K.G. (1985) Rainfall Simulators and USDA Erosion Research: History, Perspective, and Future. Erosion on Rangelands. Emerging Technology and Database. Proceedings Rainfall Simulator Workshop, Denver, 14-15 January 1985, 4 p.

[7] Meyer, L.D. (1994) Rainfall Simulators for Soil Erosion Research, In: Lal, R., Ed., Soil Erosion Research Methods, the Soil and Water Conservation Society and Sr Lucie Press, Taylor and Francis, Abingdon-on-Thames, Chapter No. 4, 83-104. https://doi.org/10.1201/9780203739358-4

[8] Cerdà, A. (1999) Simuladores de Lluvia y su Aplicación a la Geomorfología. Estado de la Cuestión. Cuadernos de I. Geográfica, 25, 45-84.

https://doi.org/10.18172/cig.1036 
[9] Grismer, M. (2012) Standards Vary in Studies Using Rainfall Simulators to Evaluate Erosion. California Agriculture, 66, 102-107. https://doi.org/10.3733/ca.v066n03p102

[10] Hignett, C.T., Gusli, S., Cass, A. and Besz, W. (1995) An Automated Laboratory Rainfall Simulation System with Controlled Rainfall Intensity, Raindrop Energy and Soil Drainage. Soil Technology, 8, 31-42. https://doi.org/10.1016/0933-3630(95)00004-2

[11] Abudi, I., Carmi, G. and Berliner, P. (2012) Rainfall Simulator for Feld Runoff Studies. Journal of Hydrology, 454-455, 76-81. https://doi.org/10.1016/j.jhydrol.2012.05.056

[12] Lassu, T., Seeger, M., Peters, P. and Keesstra, S.D. (2015) The Wageningen Rainfall Simulator: Set-Up and Calibration of an Indoor Nozzle-Type Rainfall Simulator for Soil Erosion Studies. Land Degradation \& Development, 26, 604-612. https://doi.org/10.1002/ldr.2360

[13] Morin, J., Goldberg, D. and Seginer, I. (1967) A Rainfall Simulator with a Rotating Disk. Transactions of the American Society of Agricultural Engineers, 10, 74-77, 79. https://doi.org/10.13031/2013.39599

[14] Bubenzer, G.D., Molnau, M. and McCool, D.K. (1985) Low Intensity Rainfall with a Rotating Disk Simulator. Transactions of the American Society of Agricultural Engineers, 28, 1230-1232. https://doi.org/10.13031/2013.32416

[15] Baumhardt, R.L. and Wendt, C.W. (1988) A User's Manual for the Rotating-Disk Rainfall Simulator. Texas Agric. Exp. Stn. MP-1654, College Station, 36 p.

[16] Aksoy, H., Erdem Unal, N., Cokgor, S., Gedikli, A., Yoon, J., Koca, K., Boran, I. and Eris, E. (2012) A Rainfall Simulator for Laboratory-Scale Assessment of RainfallRunoff-Sediment Transport Processes over a Two-Dimensional Flume. Catena, 98, 63-72. https://doi.org/10.1016/j.catena.2012.06.009

[17] Meyer, L.D. and Harmon, W.C. (1979) Multiple-Intensity Rainfall Simulator for Erosion Research on Row Sideslopes. Transactions of the American Society of Agricultural Engineers, 22, 100-103. https://doi.org/10.13031/2013.34973

[18] Miller, W.P. (1987) A Solenoid-Operated, Variable Intensity Rainfall Simulator. Soil Science Society America Journal, 51, 832-834. https://doi.org/10.2136/sssaj1987.03615995005100030048x

[19] Hirschi, M.C., Mitchell, J.K., Feezor, D.R. and Lesikar, B.J. (1990) Microcomputer-Controlled Laboratory Rainfall Simulator. Transactions of the American Society of Agricultural Engineers, 33, 1950-1953. https://doi.org/10.13031/2013.31563

[20] Paige, G.B., Stone, J.J., Smith, J.R. and Kennedy, J.R. (2003) The Walnut Gulch Rainfall Simulator: A Computer-Controlled Variable Intensity Rainfall Simulator. Applied Engineering in Agriculture, 20, 25-31. https://doi.org/10.13031/2013.15691

[21] Dunne, T., Dietrich, W.E. and Brunengo, M.J. (1980) Simple, Portable, Equipment for Erosion Experiments under Artificial Rainfall. Journal Agricultural Engineering Research, 25, 161-168. https://doi.org/10.1016/0021-8634(80)90057-8

[22] Cerdà, A., Ibáñez, S. and Calvo, A. (1997) Design and Operation of a Small and Portable Rainfall Simulator for Rugged Terrain. Soil Technology, 11, 163-170. https://doi.org/10.1016/S0933-3630(96)00135-3

[23] Claassens, A.S. and van der Watt, H.V.H. (1993) An Inexpensive, Portable Rain Simulator: Construction and Test Data. South African Journal of Plant and Soil, 10 , 6-11. https://doi.org/10.1080/02571862.1993.10634635

[24] Esteves, M., Planchon, O., Lapetite, J.M., Silvera, N. and Cadet, P. (2000) The 
“EMIRE” Large Rainfall Simulator: Design and Field Testing. Earth Surface Processes and Landforms, 25, 681-690.

https://doi.org/10.1002/1096-9837(200007)25:7<681::AID-ESP124>3.0.CO;2-8

[25] Shelton, C.H., Von Bernuth, R.D. and Rajbhandari, S.P. (1985) A Continuous-Application Rainfall Simulator. Transactions of the American Society of Agricultural Engineers, 28, 1115-1119. https://doi.org/10.13031/2013.32397

[26] Tossell, R.W., Wall, G.J., Rudra, R.P., Dickinson, W.T. and Groenevelt, P.H. (1990) The Guelph Rainfall Simulator II: Part 2-A Comparison of Natural and Simulated Rainfall Characteristics. Canadian Agricultural Engineering, 32, 215-223.

[27] Norton, L.B. and Brown, L.C. (1992) Time-Effect on Water Erosion for Ridge Tillage. Transactions of the American Society of Agricultural Engineers, 35, 473-478. https://doi.org/10.13031/2013.28623

[28] Chappell, A., Zobeck, T.M. and Brunner, G. (2005) Using On-Nadir Spectral Reflectance to Detect Surface Changes Induced by Simulated Rainfall and Wind Tunnel Abrasion. Earth Surface Processes and Landforms, 30, 489-511. https://doi.org/10.1002/esp.1185

[29] Chappell, A., Zobeck, T.M. and Brunner, G. (2006) Using Bi-Directional Soil Spectral Reflectance to Model Soil Surface Changes Induced by Rainfall and WindTunnel Abrasion. Remote Sensing of the Environment, 102, 328-343. https://doi.org/10.1016/j.rse.2006.02.020

[30] Sosa-Perez, G. and MacDonald, L.H. (2017) Effects of Closed Roads, Traffic, and Road Decommissioning on Infiltration and Sediment Production: A Comparative Study Using Rainfall Simulations. Catena, 159, 93-105. https://doi.org/10.1016/j.catena.2017.08.004

[31] Blanquies, J., Scharff, M. and Hallock, B. (2003) The Design and Construction of a Rainfall Simulator. 34th Annual Conference and Exposition, Las Vegas, 24-28 February 2003, 10 p. http://www.owp.csus.edu/research/papers/papers/PP044.pdf 